\title{
Neuronal Depolarization Controls Brain-Derived Neurotrophic Factor-Induced Upregulation of NR2C NMDA Receptor via Calcineurin Signaling
}

\author{
Kazunori Suzuki, Masaaki Sato, Yosuke Morishima, and Shigetada Nakanishi \\ Department of Molecular and Systems Biology, Graduate School of Biostudies, and Department of Biological Sciences, Faculty of Medicine, Kyoto \\ University, Kyoto 606-8501, Japan
}

In the developing cerebellum, switching of subunit composition of NMDA receptors occurs in granule cells from NR2B subunitcontaining receptors to NR2C subunit-containing receptors. This switching of subunit composition plays an important role in the establishment of functional mossy fiber-granule cell synaptic transmission in the mature cerebellar network. The mechanism underlying NR2C upregulation in developing granule cells, however, has to date remained to be determined. In granule cells cultured in low (5 $\mathrm{mm}$ ) $\mathrm{KCl}$, brain-derived neurotrophic factor (BDNF) upregulated NR2C mRNA via the TrkB- extracellular signal-regulated kinase (ERK) $1 / 2$ cascade and promoted the formation of an NR2C-containing NMDA receptor complex. In granule cells cultured in high $(25 \mathrm{mM}) \mathrm{KCl}$, depolarization stimulated voltage-sensitive $\mathrm{Ca}^{2+}$ channels. The resultant increase in intracellular $\mathrm{Ca}^{2+}$ activated $\mathrm{Ca}^{2+} /$ calmodulindependent calcineurin phosphatase and blocked NR2C mRNA upregulation. Interestingly, the depolarization-induced $\mathrm{Ca}^{2+}$ increase simultaneously upregulated BDNF mRNA via $\mathrm{Ca}^{2+} /$ calmodulin-dependent protein kinase (CaMK). Consequently, when calcineurin was inhibited by its inhibitor FK506 under the depolarizing condition, the CaMK-mediated increase in BDNF became a stimulatory signal, and the endogenous BDNF autocrine system was capable of upregulating NR2C mRNA via the common TrkB-ERK cascade. The importance of the BDNF-TrkB pathway was further supported by a significant reduction in NR2C in normally migrated granule cells of TrkB $B^{-/-}$ knock-out mice in vivo. The convergent mechanism of the $\mathrm{BDNF}$ and $\mathrm{Ca}^{2+}$ signaling cascades thus plays an important regulatory role in NR2C induction in granule cells during cerebellar development.

Key words: gene regulation; NMDA receptor; BDNF; cerebellar granule cell; calcineurin; ERK

\section{Introduction}

Switching of subunit composition of neurotransmitter receptors represents a hallmark of development and maturation of functional synapse formation during the early postnatal period (Farrant et al., 1994; Sheng et al., 1994; Sanes and Lichtman, 2001). NMDA receptors are glutamate-gated ion channels composed of a common NR1 subunit and distinct combinations of NR2 subunits, known as NR2A-2D (Nakanishi, 1992). Cerebellar granule cells express NR1, NR2A, and NR2B mRNAs after division in the external granule cell layer (EGL) (Akazawa et al., 1994; Watanabe et al., 1994). These cells downregulate NR2B mRNA and upregulate markedly NR2C mRNA after migration into the internal

Received May 31, 2005; revised Aug. 31, 2005; accepted Sept. 1, 2005.

This work was supported in part by research grants from the Ministry of Education, Science, and Culture of Japan. K.S., M.S., and Y.M. are fellows of the Japan Society for the Promotion of Science. We thank Eisuke Nishida for the gift of dnMEK cDNAs, Kohei Kometani and Nagahiro Minato for invaluable technical advice, and Kumlesh K. Dev for careful reading of this manuscript.

Correspondence should be addressed to Dr. Shigetada Nakanishi, Department of Systems Biology, Osaka Bioscience Institute, 6-2-4 Furuedai, Suita, 0saka 565-0874, Japan. E-mail: snakanis@obi.or.jp.

M. Sato's present address: Department of Physiology, University of California, 513 Parnassus Avenue, San Francisco, CA 94143-0444.

Y. Morishima's present address: Department of Cognitive Neuroscience, Graduate School of Medicine, The University of Tokyo, 7-3-1 Hongo, Bunkyo-ku, Tokyo 113-0033, Japan.

DOI:10.1523/JNEUROSCI.2191-05.2005

Copyright $\odot 2005$ Society for Neuroscience $\quad$ 0270-6474/05/259535-09\$15.00/0 granule cell layer (IGL) (Akazawa et al., 1994; Farrant et al., 1994; Watanabe et al., 1994). This switching of subunit composition changes the properties of NMDA receptors and contributes to synaptic transmission at the mossy fiber-granule cell in the mature cerebellar network (Farrant et al., 1994; Kadotani et al., 1996).

The mechanism underlying NR2C upregulation in granule cells has not been fully understood. Neuregulin- $\beta$ has been shown to upregulate expression of NR2C in cerebellar slice culture (Ozaki et al., 1997). However, this stimulatory effect of neuregulin- $\beta$ could not be recapitulated in culture of dissociated granule cells (Rieff et al., 1999). Several lines of evidence have suggested that brain-derived neurotrophic factor (BDNF) is an attractive candidate mediator that is implicated in NR2C upregulation in developing granule cells. BDNF and its TrkB receptor are expressed in granule cells during cerebellar development and significantly increase at the IGL after migration (Masana et al., 1993; Borghesani et al., 2002). The $B D N F^{-/}$knock-out mice showed defects in proliferation and migration of granule cells (Schwartz et al., 1997; Borghesani et al., 2002), but the TrkB ${ }^{-/-}$ knock-out mice exhibited no alteration in granule cell migration, nor in the formation of a cerebellar architecture during cerebellar development (Minichiello and Klein, 1996; Rico et al., 2002). These findings suggested that the BDNF-TrkB signaling cascade 
differentially regulates the proliferation, migration, and maturation of granule cells and participates in regulatory mechanisms of granule cell development.

The depolarizing condition with high $(25 \mathrm{~mm}) \mathrm{KCl}$ is required for the long-term survival of rat granule cells in culture (Gallo et al., 1987; Bessho et al., 1994). In contrast, the long-term viability of mouse granule cells is maintained under both high (25 mM) and low (5 mM) KCl concentrations (Mogensen et al., 1994; Mellor et al., 1998). We examined the effect of BDNF on NR2C mRNA expression under low and high $\mathrm{KCl}$ concentrations. We found that BDNF upregulates NR2C mRNA in culture of mouse granule cells grown in low $\mathrm{KCl}$ but failed to do so in granule cells grown in high $\mathrm{KCl}$. This finding provided a unique opportunity to investigate how intracellular signaling mechanisms stimulate or depress BDNF-mediated expression of NR2C mRNA in granule cells in culture and how the BDNF-mediated signaling cascade is implicated in development of granule cells in vivo. Here, we report a novel mechanism in which neuronal depolarization controls BDNF/TrkB-induced expression of NR2C mRNA via $\mathrm{Ca}^{2+}$-dependent calcineurin activation.

\section{Materials and Methods}

Culture of cerebellar granule cells. Cerebella were prepared from 8-d-old Institute of Cancer Research (ICR) mice (Japan SLC, Hamamatsu, Japan) or those of $\operatorname{TrkB}{ }^{-/-}$knock-out mice and their heterozygous and wild-type littermates (The Jackson Laboratory, Bar Harbor, ME). Cell dissociation, plating, and culture of granule cells were performed as described previously (Sato et al., 2001). Granule cells were plated on polyD-lysine-coated dishes (Becton Dickinson, Franklin Lakes, NJ) at a density of $1.5-2 \times 10^{5}$ cells $/ \mathrm{cm}^{2}$ in the serum-containing medium (Sato et al., 2001) for $24 \mathrm{~h}$ in the presence of either $5 \mathrm{~mm} \mathrm{KCl}$ or $25 \mathrm{~mm} \mathrm{KCl}$. The culture medium was switched to the serum-free medium with the same concentration of $\mathrm{KCl}$. Staining with anti- $\beta$-tubulin type III antibody showed that the cultures contained $\sim 90 \%$ neuronal cells. In some experiments, granule cells were purified ( $\sim 98 \%$ ) by centrifugation in a gradient of 35 and $60 \%$ Percoll (Sigma, St. Louis, MO) at $4000 \times g$ for $10 \mathrm{~min}$ (Hatten, 1985). Cells were cultured in the presence and absence of BDNF $(50 \mathrm{ng} / \mathrm{ml})$ or FK506 $(1 \mu \mathrm{M})$ for $96 \mathrm{~h}$, unless stated otherwise. Inhibitors of intracellular signaling cascades were added to the culture medium twice $30 \mathrm{~min}$ before and $24 \mathrm{~h}$ after the addition of BDNF and/or FK506, and cell culture was continued for $48 \mathrm{~h}$. Anti-BDNF antibody (Promega, Madison, WI) was incubated $30 \mathrm{~min}$ before the addition of FK506 to absorb endogenous BDNF released into the culture medium. Assays of nuclear factor of activated T cells (NFAT)-dependent gene expression were conducted with use of the NFAT-inhibitory peptide as described previously (Aramburu et al., 1999). Cell viability was measured with the LIVE/DEAD Viability/Cytotoxicity kit (Molecular Probes, Eugene, OR). Intracellular $\mathrm{Ca}^{2+}$ concentrations $\left(\left[\mathrm{Ca}^{2+}\right]_{\mathrm{i}}\right)$ in cultured cells were determined by $\mathrm{Ca}^{2+}$ imaging of fura-2-loaded cells as described previously (Bessho et al., 1994). Cerebellar slices were prepared from 8-d-old ICR mice and cultured as described previously (Ozaki et al., 1997). Slice cultures were conducted at $33^{\circ} \mathrm{C}$ in the humidified atmosphere with $5 \% \mathrm{CO}_{2}$. Slices were treated with or without $1 \mu \mathrm{M}$ FK506 for $96 \mathrm{~h}$, and $0.5 \mathrm{vol}$ of the culture medium was changed every $2 \mathrm{~d}$. Reagents and inhibitors were purchased from the following sources: BDNF (Peprotech, London, UK); neurotrophin-3 (NT-3), NT-4, and nerve growth factor (NGF) (Alomone Laboratories, Jerusalem, Israel); neuregulin- $\beta$ (NeoMarkers, Fremont, CA); nifedipine (Nacalai Tesque, Kyoto, Japan); KN62 (Tocris, Bristol, UK); and U0126, SB203580, FK506, K252a, U73122, PD98059, cyclosporin A, rapamycin, and bisindolylmaleimide I (Calbiochem, San Diego, CA).

RNA blotting, PCR, in situ hybridization, and nuclear run-on assay. RNA blotting was performed by electrophoresing total RNA (10 or 15 $\mu \mathrm{g}$ ) on a formalin-containing 1.2\% agarose gel (Sato et al., 2001). Radioactivities were quantified with a BAS 5000 Bioimaging Analyzer (Fuji, Kanagawa, Japan). Cerebellar RNA was isolated from at least three pups at postnatal day 8 (P8), P11, and P14, and each was subjected to either RNA blotting or quantitative PCR analysis. PCR was performed as de- scribed previously (Yamazaki et al., 2004) in triplicate with the glyceraldehyde-3-phosphate dehydrogenase (GAPDH) mRNA as an internal control marker for normalization of mRNA levels examined. In situ hybridization of parasagittal cerebellar sections $(10 \mu \mathrm{m})$ was performed with use of the digoxigenin-labeled RNA probe as described previously (Yamazaki et al., 2004). PCR-based nuclear run-on assays were performed as described previously (Rolfe and Sewell, 1997; Hartness et al., 2003).

Immunoprecipitation, Western blotting, BDNF ELISA analysis, and cellsurface biotinylation. For immnoprecipitation of an NMDA receptor complex, P2 membrane fractions (Kitano et al., 2002) were solubilized in radioimmunoprecipitation assay (RIPA) buffer $(50 \mathrm{~mm}$ Tris- $\mathrm{HCl}, \mathrm{pH}$ 7.4, $150 \mathrm{~mm} \mathrm{NaCl}, 2$ mм EDTA, 1\% Triton X-100, 0.5\% sodium deoxycholate, and $0.1 \%$ SDS) supplemented with Complete protease inhibitor mixture (Roche Diagnostics, Penzberg, Germany) and reacted with antiNR1 antibody, followed by attachment to protein G-Sepharose (Amersham Biosciences, Buckinghamshire, UK). For Western blotting, supernatants of sonicated cells or immnoprecipitates were electrophoresed on a $5-20 \%$ gradient polyacrylamide gel. For BDNF ELISA analysis, cells were cultured in 5 and $25 \mathrm{~mm} \mathrm{KCl}$ for $5 \mathrm{~d}$, and the culture medium containing secreted BDNF was concentrated 30 -fold using Centricon-10 devices (Millipore, Bedford, MA). The ELISA of released BDNF was performed in duplicate with use of a BDNF $E_{\max }$ immunoassay system (Promega) according to the manufacturer's protocol. For biotinylation of cell-surface proteins, cells were incubated with $0.3 \mathrm{mg} / \mathrm{ml}$ Sulfo-NHSSS-Biotin (Pierce, Rockford, IL) at $4^{\circ} \mathrm{C}$ for $30 \mathrm{~min}$. Cells were washed with $137 \mathrm{~mm} \mathrm{NaCl}$ and $20 \mathrm{~mm}$ Tris-HCl, pH 7.5, and lysed in RIPA buffer. Biotinylated proteins were precipitated with UltraLink Immobilized NeutrAvidin beads (Pierce), followed by Western blotting. The antibodies used included mouse anti-NR1 (1:10,000; PharMingen, San Diego, CA), anti-TrkB (1:1000; BD Biosciences, San Jose, CA), rabbit antipanNR2 (1:400; Affinity BioReagents, Golden, CO), anti-extracellular signal-regulated kinase1/2 (ERK1/2), anti-phospho-ERK1/2 (1:1000; Cell Signaling Technology, Beverly, MA), anti-ERK5, and anti-phosphoERK5 (1:2000; Calbiochem). Antibody against human phosphorylated TrkB at Tyr490 (1:1000; Cell Signaling Technology) cross-reacted with mouse phosphorylated TrkB at Tyr515 at the corresponding sequence and was used for immunoblotting to identify mouse phosphorylated TrkB. Immunoblots were reacted with horseradish peroxidaseconjugated secondary antibody and developed with ECL reagents (Amersham Biosciences).

cDNA transfection and fluorescence-activated cell sorting. The dominant-negative mitogen-activated protein kinase kinase 1/2 (dnMEK1/2) and dnMEK5 cDNAs (Kamakura et al., 1999; Torii et al., 2004) were inserted into the pEGFP vector (Clontech, Palo Alto, CA) and transfected into granule cells using the Mouse Neuron Nucleofector kit and the Nucleofector device (Amaxa, Cologne, Germany) according to the manufacturer's protocol. Transfected cells were treated with 2.5 $\mathrm{mg} / \mathrm{ml}$ trypsin and $1 \mathrm{~mm}$ EDTA at $37^{\circ} \mathrm{C}$ for $10 \mathrm{~min}$ and resuspended in the culture medium. Green fluorescent protein (GFP)-positive cells were collected by fluorescence-activated cell sorting (FACS). The efficiency of DNA transfection was $\sim 2 \%$, and FACS gave rise to $>95 \%$ GFP-positive cells. The GFP-positive cells $\left(\sim 1 \times 10^{5}\right.$ cells $)$ were put into RNAlater (Ambion, Austin, TX), and total RNA was subjected to PCR (Yamazaki et al., 2004).

Statistical analysis. Data were statistically analyzed by Student's $t$ test. Data are expressed as mean \pm SEM.

\section{Results}

\section{BDNF-induced upregulation of NR2C mRNA}

Primary cultures of cerebellar granule cells were prepared from 8 -d-old mouse pups. Twenty-four hours after plating, cells were cultured in low ( $5 \mathrm{~mm})$ and high $(25 \mathrm{~mm}) \mathrm{KCl}$ and treated with or without BDNF for $96 \mathrm{~h}$. The cell viability of granule cells cultured for $96 \mathrm{~h}$ was not influenced by different culture conditions: the fractions of viable cells per total cells were calculated to be $83.5 \pm$ $1.8 \%$ in $5 \mathrm{~mm} \mathrm{KCl} / \mathrm{BDNF}(-), 81.7 \pm 1.3 \%$ in $5 \mathrm{~mm} \mathrm{KCl} /$ $\mathrm{BDNF}(+), 82.5 \pm 1.3 \%$ in $25 \mathrm{mM} \mathrm{KCl} / \mathrm{BDNF}(-)$, and $83.2 \pm$ 
A

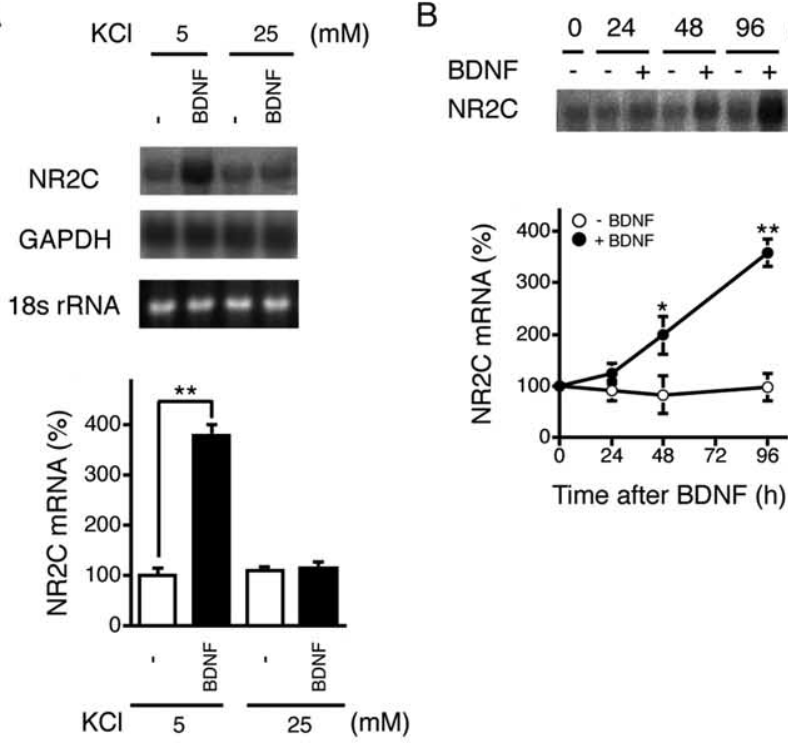

C
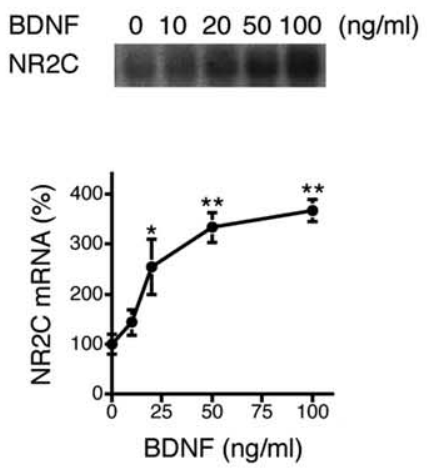

D

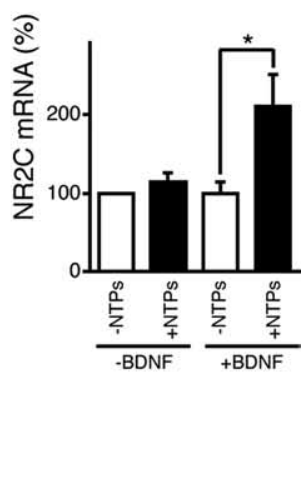

Figure 1. Upregulation of NR2C mRNA by BDNF stimulation. Representative data of NR2C and GAPDH mRNA blots and ethidium bromide-stained $18 \mathrm{~s}$ rRNA and quantitative data of NR2C $\mathrm{mRNA}$ blotting analysis are indicated. $A$, Cells were treated with or without $50 \mathrm{ng} / \mathrm{ml} \mathrm{BDNF}$ in low $(5 \mathrm{~mm}$ ) and high ( $25 \mathrm{~mm}$ ) KCl for $96 \mathrm{~h}$. Levels of NR2C $\mathrm{mRNA}$ were quantitated by RNA blotting of total RNAs (15 $\mu \mathrm{g}$ per lane; $n=4) .{ }^{* *} p<0.01$. B, Time course of NR2C mRNA upregulation by the addition of BDNF (100 ng/ml) in granule cells cultured in low KCl ( $\left.n=4\right)$. ${ }^{*} p<0.05,{ }^{* *} p<0.01, \mathrm{BDNF}^{*}$ stimulated versus unstimulated. $C$, Dose-response relationship of BDNF-induced NR2C mRNA upregulation. Cells were cultured in low KCl and treated with the indicated concentrations of BDNF for $96 \mathrm{~h}(n=4) .{ }^{*} p<0.05,{ }^{* *} p<0.01$, BDNF stimulated versus unstimulated. D, PCR-based nuclear run-on assays. Cells were cultured in low KCl and treated with or without $50 \mathrm{ng} / \mathrm{ml} \mathrm{BDNF}$ for $96 \mathrm{~h}$. Nuclei were isolated from BDNF-treated and untreated cells and incubated for $50 \mathrm{~min}$ in the presence and absence of four nucleotide triphosphates (NTPs). RNA was extracted, and levels of run-on NR2C mRNA were quantitated by PCR analysis $(n=3) .{ }^{*} p<0.05$. Error bars indicate SEM.

$2.6 \%$ in $25 \mathrm{~mm} \mathrm{KCl} / \mathrm{BDNF}(+)(n=4)$. RNA blot analysis showed that BDNF continuously increased NR2C mRNA expression up to at least $96 \mathrm{~h}$ in cells cultured with low $\mathrm{KCl}$ but failed to do so in cells cultured with high $\mathrm{KCl}$ (Fig. $1 A, B$ ). Neither the housekeeping GAPDH mRNA nor 18s rRNA was influenced by the addition of BDNF under both conditions (Fig. $1 A$ ). This observation was also confirmed in culture of granule cells enriched by Percoll gradient centrifugation. Dose-response analysis showed a halfmaximal effective concentration of $\sim 20 \mathrm{ng}$ of $\mathrm{BDNF} / \mathrm{ml}$ and the saturating level with $50 \mathrm{ng}$ of BDNF/ml (Fig. 1C). This range of effective BDNF concentrations was in a good agreement with those reported for other BDNF-regulated genes in cultured granule cells (Leingartner et al., 1994; Bulleit and Hsieh, 2000).

To examine whether BDNF upregulates NR2C mRNA at the transcriptional level, run-on experiments were performed on nuclei isolated from granule cells cultured in low $\mathrm{KCl}$ with and without BDNF treatment (Fig. 1D). The amounts of run-on NR2C mRNA were significantly higher in nuclei of BDNFtreated cells than those of untreated cells (Fig. 1D). The results indicate that BDNF upregulates NR2C mRNA expression at the transcriptional level, depending on the depolarization state of cultured granule cells.

\section{The BDNF-TrkB signaling cascade for NR2C upregulation}

We examined the specificity of mRNA induction for the NMDA receptor family after treatment with BDNF. BDNF slightly upregulated NR1 mRNA, but the extent of this upregulation was much lower than that of NR2C mRNA (Fig. $2 A$ ). No such induction was observed for NR2A or NR2B mRNA. Western blot analysis confirmed that BDNF increased protein levels of NR2C $(310 \pm 5 \% ; n=2)$ but not those of NR1 $(108 \pm 4 \% ; n=3)$ and NR2A/2B (104 $\pm 20 \% ; n=3$ ) (Fig. $2 B$ ). BDNF thus preferentially upregulates NR2C in cultured granule cells. The results also suggest that the downregulation of NR2B during granule cell maturation occurs by mechanisms other than the BDNF signaling pathway.

We examined whether BDNF increases an NR2C component in the NMDA receptor-channel complex in granule cells grown in low $\mathrm{KCl}$. This analysis was conducted by immunoprecipitation of P2 membrane fractions with anti-NR1 antibody, followed by immunoblotting with anti-panNR2 antibody. The result showed that an NR2C component is increasingly incorporated into an NMDA receptor-channel complex after BDNF treatment $[\operatorname{BDNF}(+)$ vs $\operatorname{BDNF}(-), 233 \pm 32 \% ; n=3$ ] (Fig. 2C). In contrast, no such increase occurred for the NR2A/NR2B components in the NMDA receptor complex after BDNF treatment $[\operatorname{BDNF}(+)$ vs $\operatorname{BDNF}(-), 102 \pm 7 \% ; n=3$ ] (Fig. $2 C$ ).

Next, we examined whether BDNF-upregulated NR2C is expressed in cell-surface membranes of granule cells. BDNF-treated and untreated cells were biotinylated with membraneimpermeable biotin ester. In control, no cytoplasmic actin was biotinylated under the experimental condition (data not shown). The NR2A/NR2B and NR2C subunits were all biotinylated at cell-surface membranes and precipitated by avidin beads (Fig. 2D). Importantly, the amounts of biotinylated cell-surface NR2C markedly increased in BDNF-treated granule cells compared with untreated cells $(363 \pm 37 \% ; n=3)$. This increase was in contrast to no appreciable changes of cell-surface NR2A/NR2B in BDNF-treated cells $[\operatorname{BDNF}(+)$ vs $\operatorname{BDNF}(-), 117 \pm 9 \% ; n=3]$ (Fig. 2D). The results indicate that the BDNF-upregulated NR2C is integrated into an NMDA receptor-channel complex and expressed in cell-surface membranes.

Neurotrophins exert their effects through activation of three different Trk receptors (Huang and Reichardt, 2001, 2003). BDNF and NT-4 activate TrkB, whereas NGF is specific for TrkA. NT-3 fully activates TrkC and less efficiently the other Trk receptors. NT-4 $(50 \mathrm{ng} / \mathrm{ml})$ upregulated NR2C mRNA to a similar extent with BDNF (Fig. 2E). NT-3 (50 ng/ml) also moderately 
increased NR2C mRNA, reflecting its cross-interaction with TrkB, but NGF (50 $\mathrm{ng} / \mathrm{ml}$ ) had no effect on NR2C mRNA levels (Fig. 2E). Consistent with the previous report (Rieff et al., 1999), NR2C mRNA levels were not influenced by treatment of cultured granule cells with neuregulin- $\beta$ ( $5 \mathrm{~nm}$ ) for $96 \mathrm{~h}$ (data not shown).

We also verified the role of TrkB on NR2C mRNA upregulation by examining granule cells prepared from $\operatorname{Trk} B^{-1-}$ knock-out mice (Fig. 2F). These cells showed no NR2C mRNA induction after treatment with $\mathrm{BDNF}(n=2)$. The results indicate that BDNF upregulates NR2C mRNA via the TrkB-mediated signaling cascade in granule cells grown in low $\mathrm{KCl}$.

\section{The ERK1/2 signaling cascade for NR2C upregulation}

We next examined the downstream signaling cascade of NR2C upregulation in the BDNF-TrkB signaling pathway. Immunoblot analysis showed that BDNF stimulated phosphorylation at Tyr515 in the TrkB cytoplasmic domain, but there was no difference in time course and extent of this phosphorylation between cells cultured in low $\mathrm{KCl}$ and those cultured in high $\mathrm{KCl}$ (Fig. 3A). The downstream signaling of the BDNF-TrkB pathway is thus responsible for distinct regulation of NR2C expression under the two conditions. The tyrosine phosphorylation of $\operatorname{TrkB}$ receptor activates several downstream signaling cascades including the MEK-ERK, phosphatidylinositol-3-kinase (PI3K)/Akt kinase, and phopholipase C (PLC)- $\gamma 1$ cascades (Huang and Reichardt, 2003). We tested the signaling mechanism of the BDNF/TrkB-mediated NR2C mRNA upregulation in granule cells cultured in low $\mathrm{KCl}$ by selective signaling inhibitors (Fig. $3 B$ ). The cell viability remained unchanged for at least $48 \mathrm{~h}$ but was slightly reduced $96 \mathrm{~h}$ after treatment with the MEK inhibitor U0126 (20 $\mu \mathrm{M})$ (Favata et al., 1998) and the PI3K inhibitor 2-(4-morpholinyl)-8-phenyl-4H-1-benzopyran-4-one (LY294002) $(10 \mu \mathrm{M})$ (Vlahos et al., 1994). We therefore examined the effects of signaling inhibitors in culture $48 \mathrm{~h}$ after treatment with various inhibitors (Fig. 3B). The tyrosine kinase inhibitor K252a (50 nM) (Tapley et al., 1992) and the MEK inhibitors U0126 $(20 \mu \mathrm{M})$ and PD98059 (50 $\mu \mathrm{M})$ (Pang et al., 1995) all blocked BDNF-induced NR2C mRNA upregulation (Fig. $3 B$ and data not shown). In contrast, the p38 mitogen-activated protein kinase (MAPK) inhibitor SB203580 (5 $\mu \mathrm{M}$ ) (Cuenda et al., 1995), the PI3K inhibitor LY294002 $(10 \mu \mathrm{M})$, or the broad spectrum PLC inhibitor U73122 (2 $\mu \mathrm{M})$ (Chen et al., 1994) had no effect on NR2C mRNA upregulation by BDNF (Fig. 3B). All of these inhibitors were confirmed to be effective in inhibiting the activities of target kinases or enzyme in cultured granule cells (data not shown). 0.01. Error bars indicate SEM.
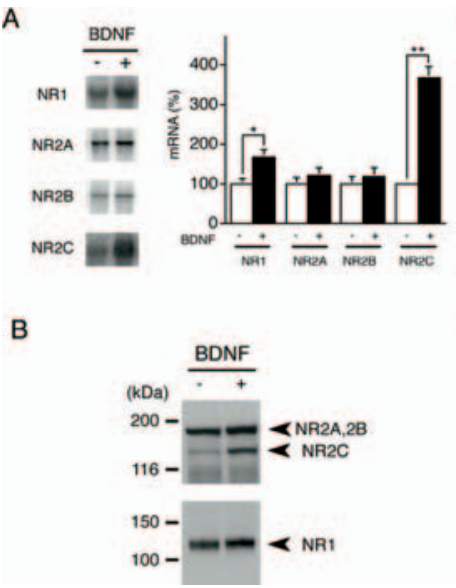

C

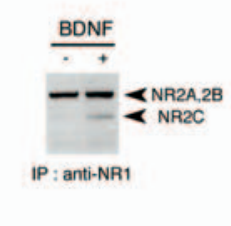

D

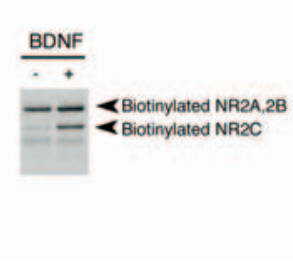

E

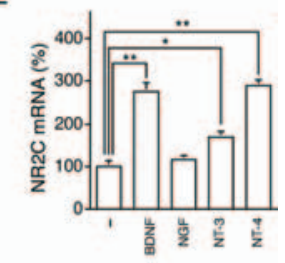

F

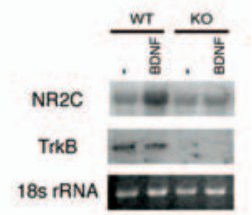

Figure 2. BDNF-induced NR2C upregulation by TrkB activation. Cells were cultured in low $\mathrm{KCl}$ and treated with or without BDNF $(100 \mathrm{ng} / \mathrm{ml}$ in $\boldsymbol{A}$ and $50 \mathrm{ng} / \mathrm{ml}$ in $\boldsymbol{B}-\boldsymbol{D}$ and $\boldsymbol{F})$ for $96 \mathrm{~h}$. $\boldsymbol{A}$, Levels of indicated mRNAs were quantitated by RNA blotting $(n=4)$. $\boldsymbol{B}$, Cell lysates $(40 \mu \mathrm{g})$ were immunoblotted with anti-panNR2 antibody or anti-NR1 antibody. Molecular sizes (kilodaltons) of protein makers are indicated on the left. C, P2 membrane fractions were isolated, solubilized, and immunoprecipitated (IP) with anti-NR1 antibody, followed by immnoblotting with anti-panNR2 antibody. D. Cell-surface proteins were biotinylated with SulfoNHS-SS-Biotin. Cell lysates were solubilized, precipitated with NeutrAvidin beads, and immunoblotted with anti-panNR2 antibody. E, Cells were cultured in low KCl and treated with BDNF, NGF, NT-3, or NT-4 (50 ng/ml each) for $96 \mathrm{~h}$. Levels of NR2C mRNA were quantitated $(n=4)$. $\boldsymbol{F}$, Granule cells were prepared from $\mathrm{TrkB}^{-1-}$ knock-out mice (KO) and their wild-type (WT) littermates. NR2C and TrkB mRNAs were analyzed by RNA blotting. Ethidium bromide-stained $18 \mathrm{~s}$ rRNA is also indicated. ${ }^{*} p<0.05 ;{ }^{* *} p<$
A

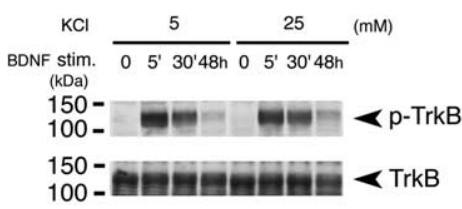

B
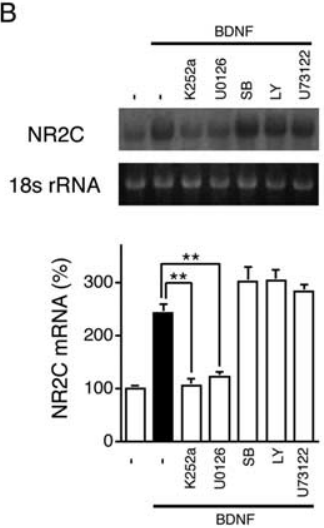

C

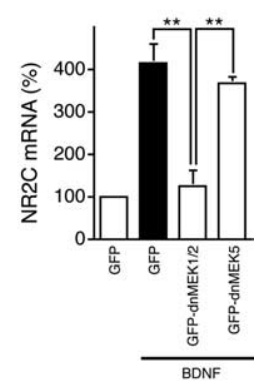

Figure 3. BDNF-induced upregulation of NR2C mRNA via the ERK1/2 signaling cascade. $A$, Cells were cultured in low and high $\mathrm{KCl}$ and treated with $50 \mathrm{ng} / \mathrm{ml} \mathrm{BDNF}$ for the indicated times. Cell lysates $(40 \mu \mathrm{g})$ were immunoblotted with antibody against either phosphorylated TrkB at Tyr515 (p-TrkB) or TrkB. stim., Stimulation. B, Cells were cultured in low KCl. These cells were preincubated for 30 min with $50 \mathrm{~nm}$ K252a, $20 \mu \mathrm{m}$ U0126, $5 \mu \mathrm{m}$ SB203580 (SB), $10 \mu \mathrm{M}$ LY294002 (LY), or $2 \mu \mathrm{m}$ U73122 and further incubated with the addition of $50 \mathrm{ng} / \mathrm{ml} \mathrm{BDNF}$ for $48 \mathrm{~h}$. Inhibitors were supplied at $24 \mathrm{~h}$ after BDNF stimulation. Representative blots of NR2C mRNA and ethidium bromide-stained 18s rRNA and quantitative data of NR2C mRNA blotting analysis are indicated $(n=3-5)$. $C$, Cells were transfected with GFP, GFP-dnMEK1/2, or GFP-dnMEK5. Transfected cells were cultured in low KCl and treated with or without $50 \mathrm{ng} / \mathrm{ml} \mathrm{BDNF}$ for $48 \mathrm{~h}$. GFP-positive cells were collected by FACS, and RNA was extracted from GFP-positive cells. Levels of NR2C mRNA were quantitated by PCR analysis $(n=3)$. ${ }^{* *} p<0.01$. Error bars indicate SEM.

Immunoblot analysis of phosphorylation of ERK1/2 and ERK5 showed that K252a (50 nM) abrogated BDNF-stimulated phosphorylation of both ERK1/2 and ERK5 but U0126 (20 $\mu \mathrm{M})$ preferentially inhibited ERK1/2 phosphorylation in cultured granule cells after BDNF treatment (data not shown). To confirm selective involvement of the MEK1/2-ERK1/2 signaling cascade in NR2C upregulation, we examined the effect of dnMEK1/2 or dnMEK5 on BDNF-mediated NR2C upregulation by transfection experiments (Fig. 3C). In this analysis, granule cells were transfected with the GFP cDNA or the cDNA encoding either 
A
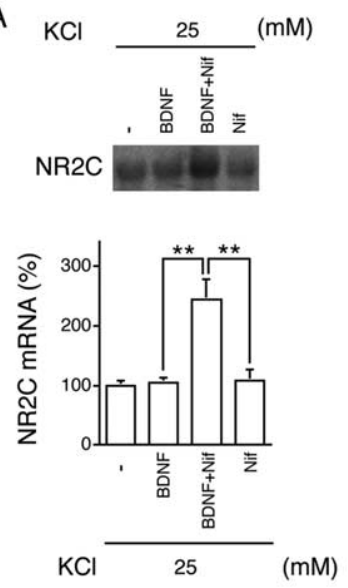

B
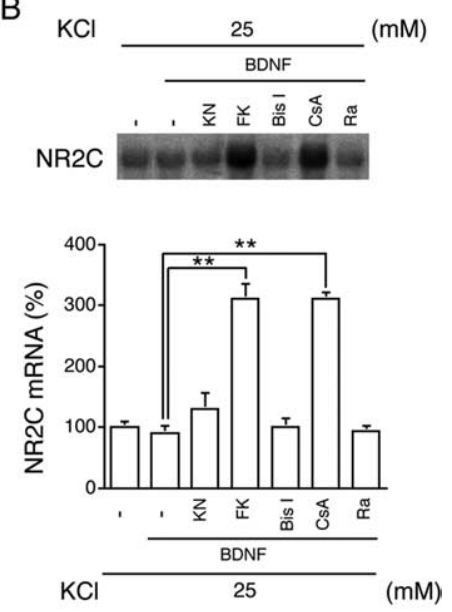

Figure 4. BDNF-induced NR2 C mRNA upregulation by L-VSCC inhibitor or calcineurin inhibitors under the depolarizing condition. Representative blots of NR2C mRNA and quantitative data of RNA blotting are indicated. $A$, Cells were cultured in high $\mathrm{KCl}$ and treated with or without $50 \mathrm{ng} / \mathrm{ml} \mathrm{BDNF}$ for $48 \mathrm{~h}$ in the presence or absence of $1 \mu \mathrm{m}$ nifedipine (Nif) $(n=4)$. B, Cells were cultured in high $\mathrm{KCl}$. These cells were preincubated for 30 min with $10 \mu \mathrm{M} \mathrm{KN} 62$ (KN), $1 \mu \mathrm{M}$ FK506 (FK), $1 \mu$ m bisindolylmaleimide I (Bis I), $500 \mathrm{~nm}$ cyclosporin A (CSA), or $1 \mu$ m rapamycin (Ra) and further incubated with or without $50 \mathrm{ng} / \mathrm{ml} \mathrm{BDNF}$ for $96 \mathrm{~h}(n=4) .{ }^{* *} p<0.01$. Error bars indicate SEM.

GFP-fused dnMEK1/2 or GFP-fused dnMEK5 and treated with BDNF ( $50 \mathrm{ng} / \mathrm{ml}$ ) for $48 \mathrm{~h}$. GFP-positive granule cells were collected by FACS and subjected to PCR analysis of NR2C mRNA expression. The BDNF-induced NR2C upregulation was completely blocked by transfection with dnMEK1/2 but not with dnMEK5 (Fig. 3C), indicating that the MEK1/2-ERK1/2 cascade is involved in downstream signaling of NR2C mRNA upregulation after the stimulation of the BDNF-TrkB pathway.

\section{Blockade of NR2C mRNA upregulation by} calcineurin activation

The above finding of the BDNF-mediated NR2C mRNA upregulation provided a unique opportunity to examine whether the TrkB-ERK1/2 signaling is operative for NR2C mRNA upregulation but blocked by some other signaling cascades in depolarized granule cells or whether the expression of NR2C mRNA is regulated by different signaling mechanisms. Depolarization of granule cells with high $\mathrm{KCl}$ activates $\mathrm{L}$-type, voltage-sensitive $\mathrm{Ca}^{2+}$ channels (L-VSCCs) and increases $\left[\mathrm{Ca}^{2+}\right]_{\mathrm{i}}$ (Bessho et al., 1994). We confirmed that resting $\left[\mathrm{Ca}^{2+}\right]_{\mathrm{i}}$ values were $70 \pm 4.2$ and $161 \pm 4.7 \mathrm{~nm}$ in granule cells cultured at 5 and $25 \mathrm{~mm} \mathrm{KCl}$ for $48 \mathrm{~h}$ $\left(n=30\right.$ each), respectively, and that this $\left[\mathrm{Ca}^{2+}\right]_{\mathrm{i}}$ increase was blocked by the L-VSCC blocker nifedipine $(80 \pm 4.1 \mathrm{nM} ; n=30)$. Remarkably, nifedipine $(1 \mu \mathrm{M})$ markedly increased NR2C mRNA in depolarized granule cells, depending on the addition of BDNF (Fig. 4A). In cells cultured in low $\mathrm{KCl}$, BDNF alone increased NR2C mRNA (Fig. 1), and this increase was not influenced by the addition of nifedipine (data not shown).

Next, we addressed whether inhibition of $\mathrm{Ca}^{2+}$-dependent protein kinase or phosphatase restores BDNF-induced NR2C mRNA upregulation in depolarized granule cells. Inhibition of $\mathrm{Ca}^{2+}$ /calmodulin-dependent calcineurin phosphatase by FK506 $(1 \mu \mathrm{M})$ (Liu et al., 1991) recovered BDNF-induced NR2C mRNA upregulation (Fig. 4B). Another calcineurin inhibitor, cyclosporin A (500 nM) (Liu et al., 1991), was also effective, but rapamycin $(1 \mu \mathrm{M})$, which does not target calcineurin (Liu et al., 1991), was ineffective (Fig. 4B). Neither the $\mathrm{Ca}^{2+} /$ calmodulin-

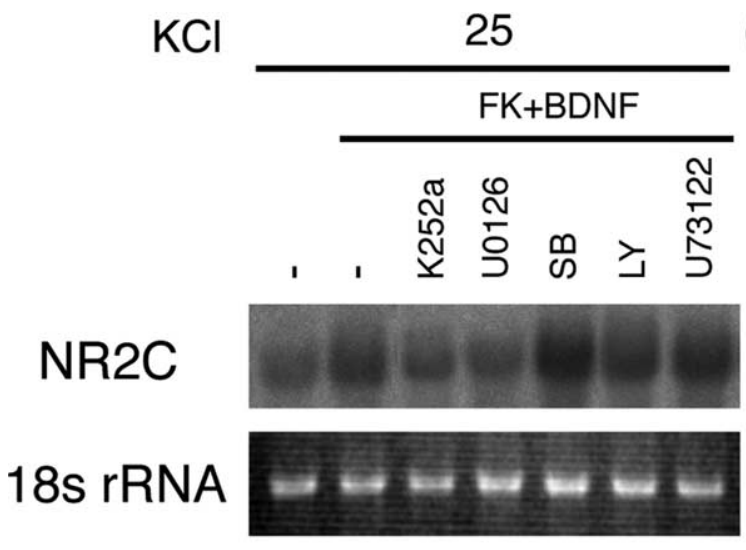

$(\mathrm{mM})$

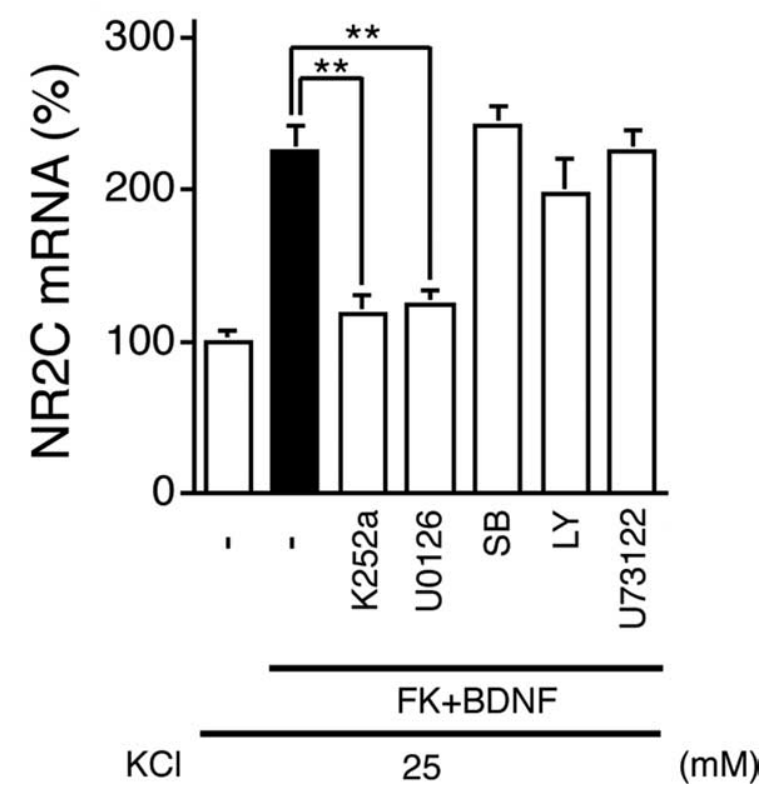

Figure 5. TrkB-ERK signaling cascade for BDNF-induced upregulation of NR2C $\mathrm{mRNA}$ under the depolarizing condition. Cells were cultured in high $\mathrm{KCl}$. These cells were preincubated for 30 min with $50 \mathrm{~nm} \mathrm{K252a,} 20 \mu \mathrm{m}$ U0126, $5 \mu \mathrm{m}$ SB203580 (SB), $10 \mu \mathrm{m}$ LY294002 (LY), or $2 \mu \mathrm{m}$ U73122 and further incubated with the addition of $50 \mathrm{ng} / \mathrm{ml}$ BDNF plus $1 \mu \mathrm{M}$ FK506 (FK) for $48 \mathrm{~h}$. Inhibitors were supplied at $24 \mathrm{~h}$ after treatment with BDNF plus FK506. Representative blots of NR2C mRNA and ethidium bromide-stained 18s rRNA and quantitative data of NR2C mRNA blotting analysis are indicated $(n=3-4) .{ }^{* *} p<0.01$. Error bars indicate SEM.

dependent protein kinase (CaMK) inhibitor KN62 (10 $\mu \mathrm{M})$ (Enslen et al., 1994) nor the protein kinase $\mathrm{C}$ inhibitor bisindolylmaleimide I (1 $\mu \mathrm{M})$ (Toullec et al., 1991) was effective in inducing BDNF-mediated NR2C mRNA upregulation (Fig. $4 B$ ). The addition of FK506 and cyclosporin A for $48 \mathrm{~h}$ had no effect on increased $\left[\mathrm{Ca}^{2+}\right]_{\mathrm{i}}$ in depolarized granule cells $(164 \pm 5.3$ and $167 \pm 9.3 \mathrm{nM}$, respectively; $n=30$ each), excluding the possibility that the calcineurin inhibitors block the L-VSCC-mediated $\mathrm{Ca}^{2+}$ influx. In addition, antagonists of NMDA receptors $[10 \mu \mathrm{M}$ MK801 ((+)-5-methyl-10,11-dihydro-5H-dibenzo [a,d] cyclohepten-5,10-imine maleate)], AMPA receptors (20 $\mu \mathrm{M}$ 6-cyano-7-nitroquinoxaline-2,3-dione), and a sodium channel blocker ( $1 \mu \mathrm{M}$ tetrodotoxin) had no inhibitory effect on BDNF/ FK506-mediated NR2C mRNA upregulation (data not shown), indicating that this upregulation results from the L-VSCCmediated increase in $\left[\mathrm{Ca}^{2+}\right]_{\mathrm{i}}$ rather than activation of neurotransmitter receptors. These results indicate that the L-VSCCstimulated increase in $\mathrm{Ca}^{2+}$ influx activates $\mathrm{Ca}^{2+}$-dependent 
calcineurin phosphatase and abrogates BDNF-induced NR2C mRNA upregulation in cultured granule cells.

\section{Role of the BDNF autocrine system in NR2C mRNA upregulation}

We pursued whether the MEK-ERK signaling cascade is also involved in upregulation of NR2C mRNA under the depolarizing condition. Similar to cells cultured in low $\mathrm{KCl}$, not only the tyrosine kinase inhibitor K252a (50 nM) and the MEK-ERK inhibitor U0126 $(20 \mu \mathrm{M})$ abrogated NR2C mRNA upregulation but also the p38 MAPK inhibitor SB203580 $(5 \mu \mathrm{M})$, the PI3K inhibitor LY294002 $(10 \mu \mathrm{M})$, and the PLC inhibitor U73122 $(2 \mu \mathrm{M})$ failed to inhibit NR2C mRNA upregulation in granule cells under the depolarizing condition in the presence of BDNF and FK506 for $48 \mathrm{~h}$ (Fig. 5). The common signaling inhibitors were thus capable of blocking NR2C mRNA upregulation in cells cultured in high and low $\mathrm{KCl}$.

The depolarization-induced $\left[\mathrm{Ca}^{2+}\right]_{\mathrm{i}}$ increase promotes induction of BDNF mRNA in neuronal cells (West et al., 2001). We therefore questioned whether the addition of exogenous BDNF is required for NR2C mRNA upregulation under the situation in which calcineurin dephosphorylation is blocked by FK506. The addition of FK506 upregulated NR2C mRNA regardless of the presence and absence of exogenously applied BDNF, and exogenous BDNF did not further enhance NR2C mRNA upregulation (Fig. 6A). This finding indicates that blockade of calcineurin activation per se is sufficient for upregulation of NR2C mRNA under the depolarizing condition. These results suggest that the de novo synthesized BDNF is capable of upregulating NR2C mRNA in depolarized granule cells, once calcineurin dephosphorylation is inhibited by FK506.

To investigate the role of the BDNF autocrine loop for NR2C mRNA upregulation, we examined the regulatory mechanisms of NR2C and BDNF mRNA induction in depolarized granule cells (Fig. $6 B$ ). In agreement with the previous report (West et al., 2001), depolarization with high $\mathrm{KCl}$ upregulated BDNF mRNA, and this increase was blocked by the CaMK inhibitor KN62. In contrast, neither BDNF nor the calcineurin inhibitor FK506 had any effect on the depolarization-induced increase in BDNF mRNA. Importantly, when BDNF mRNA induction was blocked by KN62, this blockade prevented FK506-mediated NR2C mRNA upregulation (Fig. $6 \mathrm{~B}$ ). Furthermore, the addition of exogenous BDNF restored FK506-induced NR2C mRNA upregulation in granule cells treated with KN62 (Fig. 6B). These results indicate that the $\left[\mathrm{Ca}^{2+}\right]_{\mathrm{i}}$ increase by membrane depolarization induces expression of BDNF mRNA via the $\mathrm{Ca}^{2+}$-dependent CaMK cascade and the de novo synthesized BDNF is capable of upregulating NR2C mRNA in conjunction with inhibition of calcineurin dephosphorylation.

To substantiate our findings further, we measured the amounts of BDNF released into the culture medium of granule cells grown in 5 and $25 \mathrm{~mm} \mathrm{KCl}$. After culturing under these two conditions, medium was collected, concentrated, and subjected
B
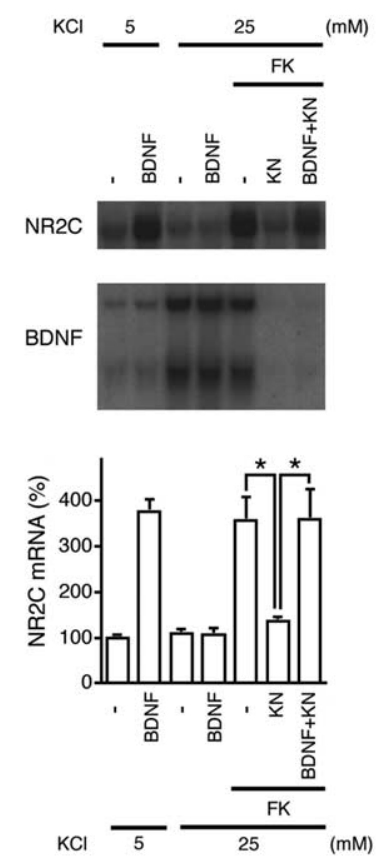

D
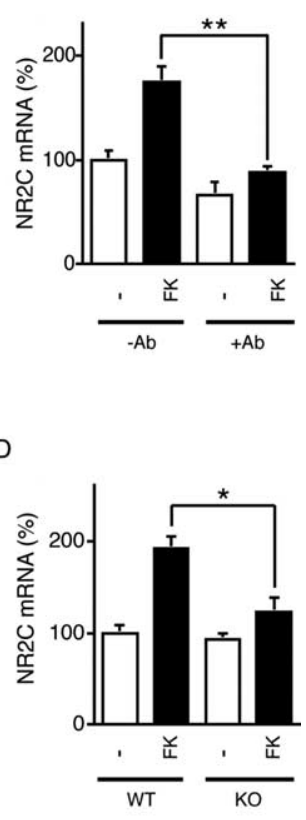

站

Figure 6. Involvement of de novo synthesized BDNF in NR2C mRNA upregulation under the depolarizing condition. Representative blots of NR2C or BDNF mRNA and quantitative data of RNA blotting analysis are indicated. $A$, Cells were cultured in high treated with or without $1 \mu \mathrm{m}$ FK506 for $48 \mathrm{~h}$. Upregulation of NR2C mRNA by FK506 treatment was significantly suppressed in knock-out mice $(n=3) .{ }^{*} p<0.05 ;{ }^{* *} p<0.01$. Error bars indicate SEM. FK, FK506.

to BDNF ELISA analysis. The amounts of released BDNF markedly increased in the culture medium in high $\mathrm{KCl}$ compared with those in low $\mathrm{KCl}(25 \mathrm{mM} \mathrm{KCl}, 141.8 \pm 8.8 \mathrm{pg} \mathrm{BDNF} / \mathrm{ml} ; 5 \mathrm{~mm}$ $\mathrm{KCl}, 31.8 \pm 3.1 \mathrm{pg} \mathrm{BDNF} / \mathrm{ml} ; n=4 ; p<0.01)$. These values agreed with those reported for both control and enhanced release of BDNF in cultured rat granule cells (Marini et al., 1998), but levels of endogenous BDNF in the culture medium were much lower than the effective concentrations of exogenous BDNF added for NR2C mRNA upregulation (Fig. 1C). This difference remains to be characterized but may be attributable to the efficient action of continuously supplied endogenous BDNF compared with a single application of exogenous BDNF or the effectiveness of endogenous BDNF in the close proximity to its receptor in cultured cells.

We also attempted to clarify the role of endogenous BDNF in NR2C induction under the depolarizing condition. We tested whether the absorption of endogenous BDNF by the addition of anti-BDNF antibody can abrogate FK506-mediated NR2C mRNA upregulation in depolarized cells (Fig. 6C). This analysis showed that FK506-induced upregulation of NR2C mRNA was abolished by incubation of depolarized cells with anti-BDNF antibody. Furthermore, NR2C mRNA induction became almost negligible when granule cells of $\operatorname{TrkB}{ }^{-1-}$ knock-out mice were treated with FK506 (Fig. 6D). These results indicate that the common BDNF/TrkB/ERK signaling has the potential to operate in granule cells cultured in both high- and low- $\mathrm{KCl}$ conditions and neuronal cell depolarization controls BDNF-induced upregula- 
A
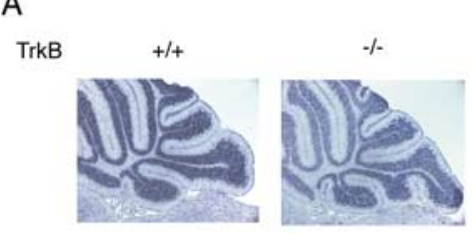

C

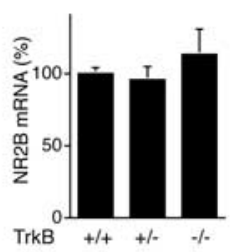

$\mathrm{E}$

D

B

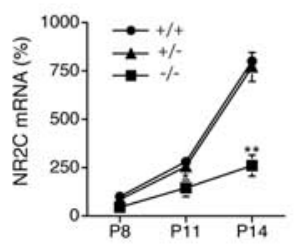

Figure 7. Decrease in NR2C mRNA and protein levels in the $T_{r k B} B^{-1-}$ cerebellum and increase in NR2C mRNA levels in FK506-treated cerebellar slice culture. $A$, In situ hybridization analysis of NR2C $\mathrm{mRNA}$ was performed with a digoxigenin-labeled antisense probe for NR2C mRNA in parasagittal sections of littermates of $T_{r k B}{ }^{-/}$and $T r k B^{+/+}$mice at P14. Hybridization signals (blue) of NR2C mRNA were greatly reduced in granule cells of $T r k B^{-/-}$mice compared with those of $T r k B^{+/+}$mice. Note also that granule cells comparably migrated into the IGL between the two genotypes. $\boldsymbol{B}$, Total RNA was isolated from cerebella of littermates of $\operatorname{TrkB}^{-/-}$, $T r k B^{+/-}$, and $\operatorname{TrkB}{ }^{+/+}$mice at P8, P11, and P14 and subjected to PCR analysis $(n=3)$. ${ }^{*} p<0.05 ;{ }^{* *} p<0.01$. C, NR2B mRNA levels in the cerebellum of the three genotypes at P14 were quantitated by PCR analysis as described in $\boldsymbol{B}$. D. Cerebellar extracts of the three genotypes at P14 were subjected to immunoblot analysis with anti-panNR2 antibody. $\boldsymbol{E}$, Slice cultures were conducted in high $\mathrm{KCl}$ and treated with or without $1 \mu \mathrm{m}$ FK506 (FK) for $96 \mathrm{~h}$. RNA was extracted, and levels of NR2C mRNA were quantitated by PCR analysis $(n=4) .{ }^{* *} p<0.01$. Error bars indicate SEM.

tion of NR2C mRNA via calcineurin dephosphorylation signaling.

\section{Involvement of TrkB in NR2C upregulation in the developing cerebellum}

Finally, we addressed whether the BDNF-TrkB pathway operates in regulation of $\mathrm{NR} 2 \mathrm{C}$ mRNA expression in the developing cerebellum in vivo. We examined the effect of TrkB deficiency on NR2C mRNA expression in the cerebellum during the early postnatal period. In agreement with previous studies (Minichiello and Klein, 1996; Rico et al., 2002), $\operatorname{TrkB} B^{-1-}$ knock-out mice showed no alteration in granule cell migration into the IGL nor in the overall cerebellar architecture at P8, P11, and P14 (Fig. 7A and data not shown). In situ hybridization analysis showed that NR2C mRNA was predominantly and increasingly expressed at granule cells in the IGL of both wild-type and $\operatorname{TrkB} B^{-/-}$mice during cerebellar development, but hybridization signals of NR2C mRNA significantly decreased in $\operatorname{TrkB}^{-1-}$ mice compared with wildtype mice throughout the postnatal period (Fig. 7A). Expression levels of NR2C mRNA were quantitatively analyzed by PCR of cerebellar RNA of $\operatorname{TrkB}^{-/-}$mice and their $\operatorname{TrkB}{ }^{+/-}$and wild-type littermates at P8, P11, and P14 (Fig. 7B). There was no difference in a temporal expression pattern of NR2C mRNA between $\mathrm{TrkB}^{+/-}$and wild-type mice, but NR2C mRNA levels were greatly reduced in $\operatorname{TrkB} B^{-/-}$knock-out mice at P11 (45 $\pm 18 \%$ of wild-type; $n=3$ ) and P14 (33 $\pm 8 \%$ of wild-type; $n=3$ ) (Fig. $7 B$ ). Furthermore, consistent with cultured granule cells, NR2B mRNA levels were unchanged in the developing cerebella (P8, P11, and P14) of the three genotypes (Fig. 7C). Western blot analysis confirmed that TrkB deficiency decreased protein levels of NR2C ( $39 \pm 4 \%$ of wild type; $n=3$ ) but not those of NR2A/ NR2B ( $97 \pm 5 \%$ of wild type; $n=3)$ in cerebellar extracts at P14 (Fig. 7D). A considerable reduction in NR2C levels in TrkB ${ }^{-1-}$ mice indicates that the BDNF-TrkB pathway plays a crucial role in regulatory mechanisms of NR2C expression in vivo during cerebellar development.

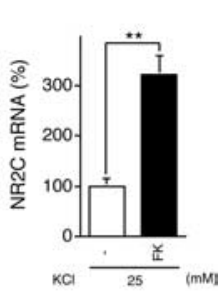

PCR and in situ hybridization analyses have indicated that mRNAs encoding $A$ and $B$ subunits of the calcineurin complex (calcineurin $\mathrm{A} \alpha, \mathrm{A} \beta$, and $\mathrm{B} 1$ ) are expressed in granule cells at the EGL and IGL during the early postnatal period (Sato et al., 2005). We examined the effect of FK506 in NR2C mRNA upregulation in cerebellar slice culture in which different cerebellar cell types undergo proliferation, migration, and differentiation in a developmentally relevant manner (Tanaka et al., 1994). Slices were prepared from P8 mouse cerebella and cultured for $5 \mathrm{~d}$ in $25 \mathrm{~mm} \mathrm{KCl}$, which sustained granule cell viability, migration, and differentiation (Tanaka et al., 1994). The addition of FK506 markedly increased NR2C mRNA levels in cerebellar slice culture (Fig. 7E), indicating that NR2C mRNA, like in dissociated granule cells, is sensitively regulated by the calcineurin signaling in cultured cerebellar slices.

\section{Discussion}

The present investigation has demonstrated that the BDNF and $\mathrm{Ca}^{2+}$ signaling cascades are integrated in regulating NR2C mRNA expression in developing cerebellar granule cells, depending on the state of membrane potentials of these cells. A model of the integrative mechanism of the BDNF and $\mathrm{Ca}^{2+}$ signals is depicted as follows (see supplemental material, available at www.jneurosci.org): in granule cells cultured in low $\mathrm{KCl}, \mathrm{L}-\mathrm{VSCC}$ are relatively inactive, and BDNF can activate the TrkB-ERK signaling cascade that leads to upregulation of NR2C. The upregulated NR2C is incorporated into a NMDA receptorchannel complex and expressed in cell-surface membranes of granule cells. In cells cultured in high $\mathrm{KCl}$, L-VSCCs are activated, and the increased $\mathrm{Ca}^{2+}$ activates CaMK, which in turn induces BDNF mRNA expression. De novo synthesized BDNF has the potential to upregulate NR2C mRNA via the common TrkBERK signaling cascade. However, an increase in $\left[\mathrm{Ca}^{2+}\right]_{\mathrm{i}}$ simultaneously activates $\mathrm{Ca}^{2+}$-dependent calcineurin phosphatase and blocks the TrkB-ERK signaling responsible for NR2C upregulation. Consequently, when calcineurin is inhibited by its inhibitors, the autocrine BDNF system now operates and upregulates NR2C mRNA. Consistent with the proposed mechanism, the FK506-mediated NR2C upregulation was blocked by treatment with anti-BDNF and greatly reduced in $\operatorname{TrkB} B^{-/-}$granule cells. Importantly, the significant reduction in NR2C was also confirmed in developing granule cells in the TrkB ${ }^{-/-}$cerebellum in vivo, indicating that the BDNF-TrkB signaling pathway plays a pivotal role in NR2C induction in granule cells during the postnatal period. MEK inhibitors and dnMEK transfection also indicated that the MEK1/2-ERK1/2 signaling is implicated in NR2C upregulation in the BDNF-TrkB pathway. After Western blot analysis, however, ERK1/2 was found to be phosphorylated after BDNF treatment with a similar extent and time course between granule cells cultured in high and low $\mathrm{KCl}$ (data not shown). This finding has indicated that calcineurin most likely acts downstream of the ERK $1 / 2$ cascade. Although the target of calcineurin dephosphorylation remains elusive, the important finding of this investigation is that the $\mathrm{BDNF}$ and $\mathrm{Ca}^{2+}$ signaling cascades form 
a convergent signaling circuit that serves as a vital role in the regulation of NR2C mRNA induction in cerebellar granule cells.

Extensive studies have disclosed the molecular mechanisms of the BDNF expression that is preferentially regulated by L-VSCCmediated $\mathrm{Ca}^{2+}$ influx among several distinct routes of intracellular $\mathrm{Ca}^{2+}$ entry (West et al., 2001). In contrast, little is known about the regulatory mechanism of NR2C mRNA expression. The $1.4 \mathrm{~kb} 5$ '-upstream NR2C genomic sequence has been shown to direct the NR2C promoter-dependent expression of the lac $Z$ transgene in cerebellar granule cells in vivo (Suchanek et al., 1997), but its relevance to NR2C mRNA upregulation remains to be studied. NFAT is a well established transcription factor activated by calcineurin (Hogan et al., 2003) and is highly expressed in cerebellar granule cells (Kramer et al., 2003). We aimed to examine the involvement of NFAT in NR2C upregulation by expressing the calcineurin-binding, NFAT-inhibitory peptide (Aramburu et al., 1999) in cultured granule cells. This inhibitory peptide, although blocking the NFAT-dependent reporter gene expression, failed to upregulate NR2C mRNA expression in depolarized granule cells (data not shown). Alongside NFAT, calcineurin has been reported to control other transcription factors such as myocyte enhancer factor 2 (MEF2) and cAMP response element-binding protein (CREB) (Bito et al., 1996; McKinsey et al., 2002). The MEK1/2-ERK1/2 can also control the transcriptional activity of many immediate-early genes through the activation of the CREB and Elk-1 transcription factors (Sgambato et al., 1998; Davis et al., 2000; Sato et al., 2001). The consensus sequences for binding to the MEF2, CREB, and Elk-1 transcription factors, however, are not found in the NR2C-upstream genomic sequence (Suchanek et al., 1995). Because the NR2C expression is now revealed to be regulated by the BDNF-ERK1/2 signaling in conjunction with calcineurin dephosphorylation, the present study has raised the possibility to examine regulatory mechanisms of the NR2C expression in cerebellar granule cells.

A switch of NMDA receptor subunits during granule cell maturation alters the open time, burst lengths, and $\mathrm{Mg}^{2+}$ sensitivity of NMDA receptor channels (Farrant et al., 1994) and contributes to establishment of mature mossy fiber-granule cell synaptic transmission in the cerebellar network (Farrant et al., 1994; Kadotani et al., 1996). In culture of mouse granule cells, the resting membrane potentials were recorded to be approximately -35 $\mathrm{mV}$ and approximately $-50 \mathrm{mV}$ in granule cells grown in 25 and $5 \mathrm{~mm} \mathrm{KCl}$, respectively (Mellor et al., 1998). These changes of membrane potentials of granule cells have been reported to produce marked differences in action potential generation and spontaneous excitatory and inhibitory synaptic transmission and have profound effects on expression of GABA receptor $\alpha 6$ in cultured granule cells (Mellor et al., 1998). Importantly, the membrane potentials of granule cells cultured in high and low $\mathrm{KCl}$ are in good agreement with a progressive decrease in resting membrane potentials from immature EGL granule cells (approximately -25 $\mathrm{mV}$ ) to mature IGL granule cells (approximately $-55 \mathrm{mV}$ ) (Rossi et al., 1998). In the present investigation, the addition of FK506 markedly increased NR2C mRNA levels in not only dissociated granule cells but also in cerebellar slice culture. It is thus conceivable that the calcineurin signaling plays a role in keeping NR2C off until the resting membrane potential of granule cells falls at later points in development. BDNF and TrkB are upregulated at granule cells during development (Masana et al., 1993; Borghesani et al., 2002), and the BDNF-TrkB signaling is capable of upregulating NR2C to form mature mossy fiber-granule cell synaptic transmission. Because the NR2C subunit reduces $\mathrm{Mg}^{2+}$ sensitivity, the blockade of its expression in immature granule cells may also contribute to protect neurons from calcium overload at the early developmental stage.

Our recent genome-wide microarray analysis of FK506treated and untreated granule cells under the depolarizing condition has revealed that FK506 increases expression levels of many genes implicated in synaptic transmission and organization including NR2C and GABA receptors $\alpha 1$ and $\alpha 6$ (Sato et al., 2005). Furthermore, many of the FK506-upregulated genes, like NR2C, are upregulated in vivo and predominantly expressed at granule cells after migration into the IGL. These findings, together with those reported in the present investigation, strongly suggest that the $\mathrm{Ca}^{2+}$-dependent calcineurin signaling serves as a more general mechanism that regulates maturation and refinement of the synaptic organization during early postnatal cerebellar development.

\section{References}

Akazawa C, Shigemoto R, Bessho Y, Nakanishi S, Mizuno N (1994) Differential expression of five $N$-methyl-D-aspartate receptor subunit mRNAs in the cerebellum of developing and adult rats. J Comp Neurol 347:150-160.

Aramburu J, Yaffe MB, López-Rodríguez C, Cantley LC, Hogan PG, Rao A (1999) Affinity-driven peptide selection of an NFAT inhibitor more selective than cyclosporin A. Science 285:2129-2133.

Bessho Y, Nawa H, Nakanishi S (1994) Selective up-regulation of an NMDA receptor subunit mRNA in cultured cerebellar granule cells by $\mathrm{K}^{+}$ induced depolarization and NMDA treatment. Neuron 12:87-95.

Bito H, Deisseroth K, Tsien RW (1996) CREB phosphorylation and dephosphorylation: a $\mathrm{Ca}^{2+}$ - and stimulus duration-dependent switch for hippocampal gene expression. Cell 87:1203-1214.

Borghesani PR, Peyrin JM, Klein R, Rubin J, Carter AR, Schwartz PM, Luster A, Corfas G, Segal RA (2002) BDNF stimulates migration of cerebellar granule cells. Development 129:1435-1442.

Bulleit RF, Hsieh T (2000) MEK inhibitors block BDNF-dependent and -independent expression of $\mathrm{GABA}_{\mathrm{A}}$ receptor subunit mRNAs in cultured mouse cerebellar granule neurons. Brain Res Dev Brain Res 119:1-10.

Chen P, Xie H, Sekar MC, Gupta K, Wells A (1994) Epidermal growth factor receptor-mediated cell motility: phospholipase $\mathrm{C}$ activity is required, but mitogen-activated protein kinase activity is not sufficient for induced cell movement. J Cell Biol 127:847-857.

Cuenda A, Rouse J, Doza YN, Meier R, Cohen P, Gallagher TF, Young PR, Lee JC (1995) SB 203580 is a specific inhibitor of a MAP kinase homologue which is stimulated by cellular stresses and interleukin-1. FEBS Lett 364:229-233.

Davis S, Vanhoutte P, Pagès C, Caboche J, Laroche S (2000) The MAPK/ ERK cascade targets both Elk-1 and cAMP response element-binding protein to control long-term potentiation-dependent gene expression in the dentate gyrus in vivo. J Neurosci 20:4563-4572.

Enslen H, Sun P, Brickey D, Soderling SH, Klamo E, Soderling TR (1994) Characterization of $\mathrm{Ca}^{2+} /$ calmodulin-dependent protein kinase IV. Role in transcriptional regulation. J Biol Chem 269:15520-15527.

Farrant M, Feldmeyer D, Takahashi T, Cull-Candy SG (1994) NMDAreceptor channel diversity in the developing cerebellum. Nature 368:335-339.

Favata MF, Horiuchi KY, Manos EJ, Daulerio AJ, Stradley DA, Feeser WS, Van Dyk DE, Pitts WJ, Earl RA, Hobbs F, Copeland RA, Magolda RL, Scherle PA, Trzaskos JM (1998) Identification of a novel inhibitor of mitogen-activated protein kinase kinase. J Biol Chem 273:18623-18632.

Gallo V, Kingsbury A, Balázs R, Jørgensen OS (1987) The role of depolarization in the survival and differentiation of cerebellar granule cells in culture. J Neurosci 7:2203-2213.

Hartness ME, Brazier SP, Peers C, Bateson AN, Ashford ML, Kemp PJ (2003) Post-transcriptional control of human maxiK potassium channel activity and acute oxygen sensitivity by chronic hypoxia. J Biol Chem 278:51422-51432.

Hatten ME (1985) Neuronal regulation of astroglial morphology and proliferation in vitro. J Cell Biol 100:384-396.

Hogan PG, Chen L, Nardone J, Rao A (2003) Transcriptional regulation by calcium, calcineurin, and NFAT. Genes Dev 17:2205-2232. 
Huang EJ, Reichardt LF (2001) Neurotrophins: roles in neuronal development and function. Annu Rev Neurosci 24:677-736.

Huang EJ, Reichardt LF (2003) TRK receptors: roles in neuronal signal transduction. Annu Rev Biochem 72:609-642.

Kadotani H, Hirano T, Masugi M, Nakamura K, Nakao K, Katsuki M, Nakanishi S (1996) Motor discoordination results from combined gene disruption of the NMDA receptor NR2A and NR2C subunits, but not from single disruption of the NR2A or NR2C subunit. J Neurosci 16:7859-7867.

Kamakura S, Moriguchi T, Nishida E (1999) Activation of the protein kinase ERK5/BMK1 by receptor tyrosine kinases. Identification and characterization of a signaling pathway to the nucleus. J Biol Chem 274:26563-26571.

Kitano J, Kimura K, Yamazaki Y, Soda T, Shigemoto R, Nakajima Y, Nakanishi S (2002) Tamalin, a PDZ domain-containing protein, links a protein complex formation of group 1 metabotropic glutamate receptors and the guanine nucleotide exchange factor cytohesins. J Neurosci 22:1280-1289.

Kramer D, Fresu L, Ashby DS, Freeman TC, Genazzani AA (2003) Calcineurin controls the expression of numerous genes in cerebellar granule cells. Mol Cell Neurosci 23:325-330.

Leingartner A, Heisenberg CP, Kolbeck R, Thoenen H, Lindholm D (1994) Brain-derived neurotrophic factor increases neurotrophin-3 expression in cerebellar granule neurons. J Biol Chem 269:828-830.

Liu J, Farmer Jr JD, Lane WS, Friedman J, Weissman I, Schreiber SL (1991) Calcineurin is a common target of cyclophilin-cyclosporin A and FKBPFK506 complexes. Cell 66:807-815.

Marini AM, Rabin SJ, Lipsky RH, Mocchetti I (1998) Activity-dependent release of brain-derived neurotrophic factor underlies the neuroprotective effect of $N$-methyl-D-aspartate. J Biol Chem 273:29394-29399.

Masana Y, Wanaka A, Kato H, Asai T, Tohyama M (1993) Localization of trkB mRNA in postnatal brain development. J Neurosci Res 35:468-479.

McKinsey TA, Zhang CL, Olson EN (2002) MEF2: a calcium-dependent regulator of cell division, differentiation and death. Trends Biochem Sci 27:40-47.

Mellor JR, Merlo D, Jones A, Wisden W, Randall AD (1998) Mouse cerebellar granule cell differentiation: electrical activity regulates the $\mathrm{GABA}_{\mathrm{A}}$ receptor $\alpha 6$ subunit gene. J Neurosci 18:2822-2833.

Minichiello L, Klein R (1996) TrkB and TrkC neurotrophin receptors cooperate in promoting survival of hippocampal and cerebellar granule neurons. Genes Dev 10:2849-2858.

Mogensen HS, Hack N, Balázs R, Jørgensen OS (1994) The survival of cultured mouse cerebellar granule cells is not dependent on elevated potassium-ion concentration. Int J Dev Neurosci 12:451-460.

Nakanishi S (1992) Molecular diversity of glutamate receptors and implications for brain function. Science 258:597-603.

Ozaki M, Sasner M, Yano R, Lu HS, Buonanno A (1997) Neuregulin- $\beta$ induces expression of an NMDA-receptor subunit. Nature 390:691-694.

Pang L, Sawada T, Decker SJ, Saltiel AR (1995) Inhibition of MAP kinase kinase blocks the differentiation of $\mathrm{PC}-12$ cells induced by nerve growth factor. J Biol Chem 270:13585-13588.

Rico B, Xu B, Reichardt LF (2002) TrkB receptor signaling is required for establishment of GABAergic synapses in the cerebellum. Nat Neurosci $5: 225-233$.

Rieff HI, Raetzman LT, Sapp DW, Yeh HH, Siegel RE, Corfas G (1999)
Neuregulin induces $\mathrm{GABA}_{\mathrm{A}}$ receptor subunit expression and neurite outgrowth in cerebellar granule cells. J Neurosci 19:10757-10766.

Rolfe FG, Sewell WA (1997) Analysis of human interleukin-5 gene transcription by a novel nuclear run on method based on the polymerase chain reaction. J Immunol Methods 202:143-151.

Rossi P, De Filippi G, Armano S, Taglietti V, D’Angelo E (1998) The weaver mutation causes a loss of inward rectifier current regulation in premigratory granule cells of the mouse cerebellum. J Neurosci 18:3537-3547.

Sanes JR, Lichtman JW (2001) Induction, assembly, maturation and maintenance of a postsynaptic apparatus. Nat Rev Neurosci 2:791-805.

Sato M, Suzuki K, Nakanishi S (2001) NMDA receptor stimulation and brain-derived neurotrophic factor upregulate homer la mRNA via the mitogen-activated protein kinase cascade in cultured cerebellar granule cells. J Neurosci 21:3797-3805.

Sato M, Suzuki K, Yamazaki H, Nakanishi S (2005) A pivotal role of calcineurin signaling in development and maturation of postnatal cerebellar granule cells. Proc Natl Acad Sci USA 102:5874-5879.

Schwartz PM, Borghesani PR, Levy RL, Pomeroy SL, Segal RA (1997) Abnormal cerebellar development and foliation in $\mathrm{BDNF}^{-1-}$ mice reveals a role for neurotrophins in CNS patterning. Neuron 19:269-281.

Sgambato V, Pagès C, Rogard M, Besson MJ, Caboche J (1998) Extracellular signal-regulated kinase (ERK) controls immediate early gene induction on corticostriatal stimulation. J Neurosci 18:8814-8825.

Sheng M, Cummings J, Roldan LA, Jan YN, Jan LY (1994) Changing subunit composition of heteromeric NMDA receptors during development of rat cortex. Nature 368:144-147.

Suchanek B, Seeburg PH, Sprengel R (1995) Gene structure of the murine $N$-methyl-D-aspartate receptor subunit NR2C. J Biol Chem 270:41-44.

Suchanek B, Seeburg PH, Sprengel R (1997) Tissue specific control regions of the $N$-methyl-D-aspartate receptor subunit NR2C promoter. Biol Chem 378:929-934.

Tanaka M, Tomita A, Yoshida S, Yano M, Shimizu H (1994) Observation of the highly organized development of granule cells in rat cerebellar organotypic cultures. Brain Res 641:319-327.

Tapley P, Lamballe F, Barbacid M (1992) K252a is a selective inhibitor of the tyrosine protein kinase activity of the trk family of oncogenes and neurotrophin receptors. Oncogene 7:371-381.

Torii S, Kusakabe M, Yamamoto T, Maekawa M, Nishida E (2004) Sef is a spatial regulator for Ras/MAP kinase signaling. Dev Cell 7:33-44.

Toullec D, Pianetti P, Coste H, Bellevergue P, Grand-Perret T, Ajakane M, Baudet V, Boissin P, Boursier E, Loriolle F, Duhamel L, Charon D, Kirilovsky J (1991) The bisindolylmaleimide GF 109203 X is a potent and selective inhibitor of protein kinase C. J Biol Chem 266:15771-15781.

Vlahos CJ, Matter WF, Hui KY, Brown RF (1994) A specific inhibitor of phosphatidylinositol 3-kinase, 2-(4-morpholinyl)-8-phenyl-4H-1benzopyran-4-one (LY294002). J Biol Chem 269:5241-5248.

Watanabe M, Mishina M, Inoue Y (1994) Distinct spatiotemporal expressions of five NMDA receptor channel subunit mRNAs in the cerebellum. J Comp Neurol 343:513-519.

West AE, Chen WG, Dalva MB, Dolmetsch RE, Kornhauser JM, Shaywitz AJ, Takasu MA, Tao X, Greenberg ME (2001) Calcium regulation of neuronal gene expression. Proc Natl Acad Sci USA 98:11024-11031.

Yamazaki H, Sekiguchi M, Takamatsu M, Tanabe Y, Nakanishi S (2004) Distinct ontogenic and regional expressions of newly identified CajalRetzius cell-specific genes during neocorticogenesis. Proc Natl Acad Sci USA 101:14509-14514. 